\title{
Postharvest Fruit Rots of Apple in Greece: Pathogen Incidence and Relationships Between Fruit Quality Parameters, Cultivar Susceptibility, and Patulin Production
}

S. Konstantinou, G. S. Karaoglanidis, and G. A. Bardas, Laboratory of Plant Pathology, and I. S. Minas, Laboratory of Pomology, Aristotelian University of Thessaloniki, School of Agriculture, Thessaloniki, Greece; and E. Doukas and A. N. Markoglou, Agricultural University of Athens, Laboratory of Pesticide Science, Athens

\begin{abstract}
Konstantinou, S., Karaoglanidis, G. S., Bardas, G. A., Minas, I. S., Doukas, E., and Markoglou, A. N. 2011. Postharvest fruit rots of apple in Greece: Pathogen incidence and relationships between fruit quality parameters, cultivar susceptibility, and patulin production. Plant Dis. 95:666-672.

The incidence of pathogens associated with postharvest fruit rots on the four most extensively cultivated apple cultivars (Red Delicious, Golden Delicious, Granny Smith, and Fuji) in Greece was surveyed during two consecutive storage periods (2008-09 and 2009-10) in five packinghouses located in northern Greece. The fungi isolated were identified based on their morphological characteristics and internal transcribed spacer gene sequencing. In the four cultivars sampled, Penicillium expansum and Botrytis cinerea were the predominant pathogens, accounting for averages of 44.2 and $23.6 \%$, respectively, of the pathogens isolated from the sampled fruit. Two other important rot pathogens were Alternaria tenuissima and Mucor pyriformis, accounting for 16.1 and $6.6 \%$, respectively, of the diseased apple fruit. Other pathogens such as Monilinia laxa, M. fructigena, Botryosphaeria obtusa, Geotrichum candidum, Fusarium avenaceum, and $F$. proliferatum were isolated at low frequencies and are considered of minor importance. Measurements of the resistance level of the four apple cultivars

to fruit rot caused by $P$. expansum and Botrytis cinerea revealed that Golden Delicious was the most susceptible to blue mold while Fuji was the most susceptible to gray mold infections. Susceptibility to gray mold was negatively correlated with flavonoid and phenol concentration as well to fruit antioxidant activity, while susceptibility to blue mold was negatively correlated with fruit firmness and phenol concentration. Patulin production was significantly higher in Red Delicious and Golden Delicious fruit than in Granny Smith and Fuji fruit and was negatively correlated with the acidity of the fruit. The high incidence of $P$. expansum and A. tenuissima along with the presence of $F$. avenaceum and $F$. proliferatum, all of which are potentially mycotoxin producers, emphasize the risk for mycotoxin contamination of apple fruit juices and by-products. Furthermore, information on the distribution of the pathogens on the main cultivars may be useful for the implementation of strategies to control the diseases and minimize the threat of mycotoxin contamination on each cultivar.
\end{abstract}

More than 90 fungal species can cause fruit rot diseases on apple fruit (9). Gray mold caused by Botrytis cinerea Pers. and blue mold caused by Penicillium expansum Link are considered to be the major postharvest diseases on pome fruit. These pathogens, along with several species of Alternaria, Monilinia, Mucor, Rhizopus, Fusarium, and Botryosphaeria, have been estimated to cause 5 to $25 \%$ losses of total yield in apple during postharvest storage and commercialization (8).

Postharvest diseases of apple are the result of either latent infections that occur in the field during the growing season or infections from wounds during harvest and handling operations. Consequently, fungal pathogens associated with postharvest rots of apple can be separated into two main groups: "latent infection" and "wound" pathogens $(9,16)$. Alternaria spp., Fusarium avenaceum, Glomerella cingulata, Pezicula malicortitis, and Sphaeropsis pyriputrescens belong in the former group $(9,10,26)$. B. cinerea, Penicillium expansum, Monilinia spp., and Mucor pyriformis belong in the latter group $(8,17,20)$.

Losses caused by postharvest rots of apple are not only quantitative due to the developing decay of the fruit but also qualitative due to possible mycotoxin contamination. This is particularly important because large amounts of apple fruit are used for juice and, often, fruit designated to be used for processing and not for direct consumption are of lower quality due to fungal infections (20). Some of the fungi that infect apple produce mycotoxins which can lead

Corresponding author: G. S. Karaoglanidis,

E-mail: gkarao@agro.auth.gr

Accepted for publication 7 February 2011.

doi:10.1094/PDIS-11-10-0856

(c) 2011 The American Phytopathological Society to various human health problems, including teratogenic, cancerogenic, neurotoxic, oestrogenic, and immunosuppressive effects (7). None of the species of the major fruit rot genera on stored apple fruit (e.g., Botrytis, Monilinia, and Mucor) are known to produce a mycotoxin, whereas other species of fungal genera such as Alternaria, Aspergillus, Fusarium, and Penicillium are capable of producing a wide range of mycotoxins (13).

Patulin is by far the most important mycotoxin contaminant of apple juice and other apple products and is produced mainly by $P$. expansum (7). Due to its cytotoxic, immunotoxic, and neurotoxic effects on animals, the Joint Food and Agricultural Organization and World Health Organization Expert Committee on Food Additives has established a provisional maximum tolerable daily intake of $0.4 \mu \mathrm{g} \mathrm{kg}^{-1}$ of body weight for patulin that was endorsed by the European Union Scientific Committee for Food in 2000. The maximum permitted levels of patulin in Europe are $10 \mu \mathrm{g} \mathrm{kg}^{-1}$ for fruit baby food, $50 \mu \mathrm{g} \mathrm{kg}^{-1}$ for fruit juice, and $25 \mu \mathrm{g} \mathrm{kg}^{-1}$ for solid apple products (18). Factors affecting patulin accumulation in fruit juices include temperature, storage conditions, fruit qualitative parameters, and fungicide treatments $(19,21,25)$.

The factors that affect yield losses caused by postharvest pathogens have been reviewed by Coates and Johnson (4) and include pathogen species, commodity type, cultivar susceptibility, storage environment, qualitative characteristics of the fruit, and the treatments used for disease control. Despite the fact that the reports on the causal agents of apple fruit rot are numerous, only limited information has been provided for the relative frequency and incidence of causal agents causing postharvest rot and internal fruit spoilage $(10,29,32)$. Furthermore, the importance of each fungal pathogen can vary from country to country. Accurate knowledge of the incidence of each pathogen on the cultivars cultivated in each country along with information regarding their susceptibility to fungal pathogens is a prerequisite for the implementation of appropriate disease management strategies. 
Despite the fact that apple is one of the most important tree crops in Greece, little is known regarding the incidence of pathogens causing postharvest rots on apple fruit and the susceptibility of the main apple cultivars to postharvest pathogens. Therefore, a study was initiated to (i) identify the causal agents and determine the prevalence and incidence of postharvest fruit rot diseases of apple fruit of the main cultivars in Greece, (ii) determine the levels of susceptibility of these apple cultivars to the main pathogens causing postharvest rots and to correlate the susceptibility with the qualitative characteristics of the fruit, and (iii) investigate patulin accumulation in $P$. expansum-inoculated fruit.

\section{Materials and Methods}

Sources and sampling of fruit. The apple fruit in this study were obtained from five packinghouses located in the region of Imathia, in northern Greece, one of the main apple-cultivating regions of the country. Samples were taken at 15-day intervals from November to March (apple storage period in Greece) for 2 consecutive years (2008-09 and 2009-10). Fruit from four apple cultivars were sampled (Golden Delicious, Red Delicious, Fuji, and Granny Smith), representing the main apple cultivars of the country. In each sampling, 15 to 20 fruit per cultivar, showing decay symptoms, were arbitrarily collected from the selection line during the packing operations. In total, 1,075 rotted fruit were collected during the two sampling periods.

Pathogen isolation and identification. The sampled fruit were transported to the laboratory for fungal isolation. Isolations were carried out from surface-disinfected fruit (they were drenched for 1 min in a $1 \%$ sodium hypoclorite solution) by removing small fruit pieces at the margin of diseased/healthy tissue and transferring them to petri dishes containing acidified potato dextrose agar (PDA; Oxoid, Unipath Ltd., Basingstoke, UK). Petri dishes were incubated at $22^{\circ} \mathrm{C}$ in an incubator with a 12-h photoperiod provided by fluorescent lights. After 3 to 5 days of incubation, the emerging fungal colonies were transferred to fresh PDA medium to obtain pure cultures of the isolated fungi.

Fungal identification was based on colony appearance and morphological features of fruiting bodies and spores. Known fruit rot pathogens were identified to species based on fungal descriptions (2), while nonsporulating isolates on culture media or isolates that could not be readily identified based on morphological characteristics were identified at the species level using analysis of the nucleotide sequences of internal transcribed spacer (ITS) regions of ribosomal DNA (rDNA). In the latter group belonged fungal species of the genera Alternaria, Fusarium, Botryosphaeria, Phomopsis, and Stemphylium.

All isolates subjected to molecular identification were singlespore isolates. DNA was extracted from mycelium using Qia Puregene Core Kit A (Qiagen GmbH, Hilden, Germany) according to the manufacturer's protocol. ITS1 and ITS2 regions, including the ribosomal 5.8S RNA gene, were amplified using the universal ITS-1 (5-TCCGTAGGTGAACCTGCGG-3) and ITS-4 (5-TCCTCC GCTTATTGATATGC-3) primers that anneal to the flanking 18S and 28S rRNA genes. Polymerase chain reaction (PCR) products of each isolate were purified using the Qiaquick PCR Purification Kit (Qiagen $\mathrm{GmbH}$ ). The purified products were subjected to sequencing (Lark Technologies Inc., Essex, UK) in both directions using primers ITS-1 and ITS-4. Sequences were aligned using the computer software package Clustal W 2.0.9 (12). The sequences obtained were compared with sequences in the National Center for Biotechnology Information database using BlastN 2.2.18.

Fruit quality and compositional assays. Fruit of the four cultivars that were monitored for pathogen incidence were screened for their susceptibility to gray mold and blue mold and patulin production. Prior to the artificial inoculation with the pathogens and the measurement of patulin production, several fruit qualitative parameters were measured. The fruit were obtained from a commercial storage room $\left(0.0 \pm 0.5^{\circ} \mathrm{C}, 90 \%\right.$ relative humidity $)$ at the end of October 2009 after a short storage period of 10 to 30 days, depending on the cultivar. Fruit were selected on a basis of size and uni- formity of shape and absence of any wound. Thirty fruit without defects and with similar weight $(170 \pm 15 \mathrm{~g})$ from each cultivar, separated arbitrarily into three replicate samples, were used to assess the quality parameters and the compositional status. The sampling of the fruit was repeated 1 week later for an independent replication of the measurements.

Tissue firmness was determined on two opposite sides of each fruit. A 1-mm-thick disk of skin was removed from each side of the fruit and the force in $\mathrm{N}$, required to insert a Chatillon penetrometer fitted with a probe of $12 \mathrm{~mm}$ in diameter, was recorded. Soluble solids content (SSC) and titratable acidity (TA) were assessed in juice obtained from three replicate samples of 10 fruit per cultivar. Percent SSC was determined with a refractometer (Atago PR-1; Atago Co. Ltd., Tokyo) and TA by titration with $\mathrm{NaOH}$ at $0.1 \mathrm{~mol}$ liter $^{-1}$ to $\mathrm{pH} 8.2$ and expressed as percentage of malic acid.

Total carotenoids were determined according to the method of Kuti (11), with slight modifications. From each replicate sample, $2.5 \mathrm{~g}$ /cultivar was extracted with $20 \mathrm{ml}$ of hexane/acetone/ethanol (50:25:25, vol/vol) and centrifuged $\left(6,500 \mathrm{rpm}, 5 \mathrm{~min}, 5^{\circ} \mathrm{C}\right)$. The lipophylic phase was recovered and transferred to a $10-\mathrm{ml}$ volumetric flask, and the volume adjusted with hexane. The absorbance of the hexane solution was measured at $450 \mathrm{~nm}$ with a UV-Vis spectrophotometer (model UV-1700 Pharmaspec; Shimadzu, Kyoto, Japan) and total carotenoids were calculated using the value 2,592 as a specific extinction coefficient of $\beta$-carotene. The results were expressed as milligrams of $\beta$-carotene equivalents $(\beta-\mathrm{CE}) 100$ $\mathrm{g}^{-1}$ fresh weight (f.w.).

Fruit from each replicate sample per cultivar were homogenized and $2.5 \mathrm{~g}$ of tissue was extracted with $20 \mathrm{ml}$ of $70 \%$ acetone, containing $0.5 \%$ acetic acid, for $24 \mathrm{~h}$ at $5^{\circ} \mathrm{C}$ under darkness. The supernatant was filtered in a Buchner funnel with Whatman no. 1 filter paper into a volumetric flask and the total volume was adjusted to $25 \mathrm{ml}$ with extraction solution. The extract, kept at $5^{\circ} \mathrm{C}$ in the darkness, was used for the determination of total phenol, total flavonoids, and its antioxidant activity using the 1,1-diphenyl-2picryl hydrazyl) method (DPPH; 3).

The amount of total phenolics in apple extracts was determined according to the Folin-Ciocalteu procedure (27). Briefly, $0.25 \mathrm{ml}$ of extract was mixed with $2.5 \mathrm{ml}$ of 1:10 diluted Folin-Ciocalteu's phenol reagent, followed by $2 \mathrm{ml}$ of $7.5 \%$ (wt/vol) $\mathrm{Na}_{2} \mathrm{CO}_{3}$. After 5 min at $50^{\circ} \mathrm{C}$, samples were allowed to cool and absorbance was measured at $760 \mathrm{~nm}$ with a UV-Vis spectrophotometer (model UV1700 Pharmaspec; Shimadzu). Phenolic content was estimated from a standard curve of gallic acid and results were expressed as milligrams of gallic acid equivalents (GAE) $100 \mathrm{~g}^{-1}$ f.w.

The determination of total flavonoids was based on the color caused by the binding of $\mathrm{Al}^{+3}$ ions in flavonoids. The reaction was completed in $11 \mathrm{~min}$ and then the absorption was determined at $510 \mathrm{~nm}$ (5). Briefly, $1 \mathrm{ml}$ of extract and $2.7 \mathrm{ml}$ of distilled $\mathrm{H}_{2} \mathrm{O}$ were added to $150 \mathrm{ml}$ of $5 \% \mathrm{NaNO}_{2}, 5 \%$ and, after $5 \mathrm{~min}, 150 \mathrm{ml}$ of $10 \% \mathrm{AlCl}_{3} \cdot 6 \mathrm{H}_{2} \mathrm{O}$, were added followed by stirring in a vortex. Then, 6 min later, $1 \mathrm{ml}$ of $\mathrm{NaOH}$ at 1 mol liter $^{-1}$ was added. The final sample was mixed by vortexing and, after $90 \mathrm{~min}$, the absorbance was determined at $510 \mathrm{~nm}$ with a UV-Vis spectrophotometer. For quantification, a standard curve was constructed (0 to $100 \mu \mathrm{g}$ ) with standards of catechin. Results were expressed as catechin equivalents (CE) $\mathrm{mg} 100 \mathrm{~g}^{-1}$ f.w.

The DPPH method, used to monitor antioxidant activity, was conducted according to the modified procedure of Brand-Williams and co-workers (3). In its radical form, DPPH has an absorption band at $517 \mathrm{~nm}$ which disappears upon reduction by an antiradical compound. Briefly, $50 \mu \mathrm{l}$ of extract plus $2,950 \mu \mathrm{l}$ of a solution of

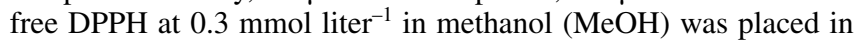
darkness at room temperature $\left(20^{\circ} \mathrm{C}\right)$. After $30 \mathrm{~min}$, the decrease in absorption of the DPPH solution at $517 \mathrm{~nm}$ was measured with a UV-Vis spectrophotometer. The antioxidant activity was expressed as milligrams of ascorbic acid equivalents antioxidant capacity (AEAC) $100 \mathrm{~g}^{-1}$ f.w.

Cultivar susceptibility measurement. One isolate each of $P$. expansum and $B$. cinerea, randomly selected from the source of the 
identified isolates, was used for the cultivar susceptibility measurement. Inoculum for both pathogens was produced on PDA in 9-cm petri dishes. Conidia were collected by adding $10 \mathrm{ml}$ of sterile distilled water to each dish and gently rubbing the sporulating colonies with a L-shaped bent glass rod. Spore concentration was adjusted with the aid of a hemacytometer to obtain a suspension containing $1 \times 10^{5}$ spores $\mathrm{ml}^{-1}$. Prior to inoculation, fruit were surface disinfested for $5 \mathrm{~min}$ by drenching them in a $1 \% \mathrm{NaOCl}$ solution. After removing them from the disinfestant solution, they were rinsed three times with sterile deionized water and subsequently air dried. The fruit were wound inoculated at the equator. Two wounds per fruit, $3 \mathrm{~mm}$ in depth, were made using a 2-mmdiameter nail head which was inserted into the fruit. On each wound, $20 \mu \mathrm{l}$ of a conidial suspension was placed with a pipette. Fruit wounded similarly but treated with sterile water were used as noninoculated controls. In all, 40 fruit per pathogen and cultivar combination were inoculated. The fruit were placed on wire mesh platforms ( 10 fruit per box) in plastic boxes ( 23 by 31 by $10 \mathrm{~cm}$ [length by width by height]). Water $(30 \mathrm{ml})$ was added in each box and the box covered to maintain high relative humidity. In total, 20 of the inoculated fruit per pathogen and cultivar combination were incubated for 7 days at $22^{\circ} \mathrm{C}$ and the remaining 20 fruit were incubated for 30 days at $2^{\circ} \mathrm{C}$. After the end of the incubation period, the infections were scored by measuring lesion diameter. The experiment was performed two times.

Patulin extraction, purification, and measurement. Patulin production measurement was conducted on the 20 apple fruit per cultivar inoculated with $P$. expansum and incubated at $22^{\circ} \mathrm{C}$ for 7 days. After the end of the incubation period and the measurement of disease severity, the diseased fruit were separated into four samples of five fruit each and ground in a blender with $75 \mathrm{ml}$ of methanol/water $(60: 40)$ for $5 \mathrm{~min}$ and the supernatant was filtrated through cheesecloth. The residual extract was partitioned with 30 $\mathrm{ml}$ of chloroform and, after evaporation to dryness, the extract was redissolved in $5 \mathrm{ml}$ of methanol and filtered through a polyvinylidene difluoride Teflon filter. Patulin was detected on thin-layer chromatography (TLC) plates by spraying them with 3-methyl-2benzothiazolinone hydrazone hydrochloride, according to a method previously described (15). The quantitative analysis of patulin was performed by a Shimadzu high-performance liquid chromatography system equipped with a binary solvent pump (LC10ADvp), DGU-14A degasser, CTO-10Avp column oven, SIL10ADvp autosampler with volume injection set at $2 \mu \mathrm{l}$, and a UV diode array detector (SPD-M10Avp). Data acquisition and processing were performed with the liquid chromatography-mass spectrometry solution Ver. 3.0 Workstation. The chromatographic separation was performed on a Discovery reversed-phase $\mathrm{C}_{18}$ narrowbore column ( 250 by $4.6 \mathrm{~mm}$ i.d., 5 - $\mu \mathrm{m}$ particle size), thermostatted at $40^{\circ} \mathrm{C}$. The mobile phase was water/acetonitrile (90:10, $\mathrm{vol} / \mathrm{vol}$ ), delivered isocratically at a flow-rate of $0.7 \mathrm{ml} \mathrm{min}^{-1}$ for $15 \mathrm{~min}$. The calibration plot was linear for the UV diode array detector over the range of 0.01 to $5 \mu \mathrm{g} \mathrm{ml}^{-1}$, and the detectable limit (log of the likelihood ratio) of the analytical method was approximately $2.5 \mathrm{ng} \mathrm{ml}^{-1}$. The recoveries from the apple samples at fortification levels of patulin at 10,50 , and $100 \mathrm{ng} \mathrm{g}^{-1}$ were 87 to $98.6 \%$, with precision values (relative standard deviation) of 7.6 to $12.5 \%$. The experiment was performed two times.

Data analysis. Data from the two independent trials on fruit qualitative parameters of the four cultivars used in the experiments, lesion diameter caused by the two pathogens on the fruit of the cultivars tested, and patulin production on fruit artificially inoculated with $P$. expansum were tested for homogeneity of variance using the Levene test. In these analyses, data of the two independent trials were considered block treatments and the replications within each trial were used as subsamples. The data of the two independent trials fulfilled the criteria for homogeneity of variance $(P>0.05)$ and, therefore, they were combined and subjected to analysis of variance. Mean values of each parameter tested were compared using Fisher's protected least significant difference test at $P=0.05$. Pearson correlation coefficients were estimated between mean values of fruit qualitative parameters, mean lesion diameters, and patulin production. Statistical analyses were conducted using SPSS (version 17.0; SPSS, Chicago) and graphs were created using Prism (v5.01; Graph Pad Inc., San Diego, CA).

\section{Results}

Fungal pathogen incidence. During the 2-year survey, more than 10 different fungi were isolated from decayed apple fruit of the four cultivars sampled (Table 1). P. expansum, B. cinerea, Alternaria tenuissima, and $M$. pyriformis were four major fruit rot pathogens isolated from all cultivars, accounting for 44.2, 23.6, 16.1, and $6.6 \%$ of the decayed fruit, respectively (Fig. 1). These four pathogens were isolated, although at different frequencies, from the four cultivars in both years of the study. Blue mold caused by $P$. expansum was the most common disease on Red Delicious, Granny Smith, and Golden Delicious during both storage periods; however, blue mold on Fuji fruit was the most common disease in 2008 but not in 2009 (Table 1). B. cinerea, causal agent of gray mold, was isolated at frequencies of 26.9 to $38.4 \%$ from fruit of Red and Golden Delicious during both years of the study. However, the frequency of gray mold on Granny Smith and Fuji varied between 2008 and 2009. During 2008, frequency of gray mold was low, accounting for only 1.9 and $3.5 \%$ of the decayed Granny Smith and Fuji fruit, respectively, compared with 21.5 and $34.2 \%$ in 2009 (Table 1). Alternaria rot caused by A. tenuissima was the third most prevalent fruit rot disease in fruit of Red Delicious, Granny Smith, and Golden Delicious at frequencies of 7.5 to $16.8 \%$. Interestingly, Alternaria rot incidence was higher in Fuji fruit, accounting for 33 and $34.2 \%$ of the rotted fruit during 2008 and 2009, respectively (Table 1). The frequency of Mucor rot ranged from $0.8 \%$ on Red Delicious in 2008 to $22.8 \%$ on Granny Smith in 2008. The incidence of other diseases, including brown

Table 1. Frequency of recovery of postharvest fungal pathogens on naturally infected fruit of four apple cultivars, sampled from packinghouses in northern Greece during 2008 and 2009

\begin{tabular}{|c|c|c|c|c|c|c|c|c|}
\hline \multirow[b]{3}{*}{ Postharvest pathogens } & \multicolumn{8}{|c|}{ Frequency of recovery $(\%)$} \\
\hline & \multicolumn{2}{|c|}{ Red Delicious } & \multicolumn{2}{|c|}{ Granny Smith } & \multicolumn{2}{|c|}{ Golden Delicious } & \multicolumn{2}{|c|}{ Fuji } \\
\hline & 2008 & 2009 & 2008 & 2009 & 2008 & 2009 & 2008 & 2009 \\
\hline Penicillium expansum & 46.5 & 43.2 & 54.2 & 58.7 & 44.0 & 35.1 & 49.0 & 20.7 \\
\hline Botrytis cinerea & 30.2 & 38.4 & 1.9 & 21.5 & 36.5 & 26.9 & 3.5 & 34.2 \\
\hline Alternaria tenuissima & 8.9 & 10.4 & 10.4 & 7.5 & 8.4 & 16.8 & 33.0 & 34.2 \\
\hline Mucor pyriformis & 5.0 & 0.8 & 22.8 & 4.1 & 2.1 & 1.4 & 12.2 & 4.5 \\
\hline Monilinia laxa & 0.7 & 0.0 & 0.0 & 0.8 & 0.0 & 0.0 & 0.0 & 3.6 \\
\hline M. fructigena & 0.7 & 1.6 & 1.9 & 0.0 & 5.3 & 3.8 & 0.0 & 1.9 \\
\hline Fusarium avenaceum & 0.0 & 3.8 & 1.1 & 2.8 & 0.0 & 1.4 & 0.0 & 0.0 \\
\hline F. proliferatum & 0.0 & 1.0 & 0.9 & 0.5 & 0.0 & 0.0 & 0.0 & 0.0 \\
\hline Geotrichum candidum & 4.6 & 0.0 & 4.7 & 4.1 & 3.2 & 0.0 & 2.3 & 0.0 \\
\hline Botryosphaeria obtusa & 2.7 & 0.8 & 1.9 & 0.0 & 0.0 & 0.0 & 0.0 & 0.0 \\
\hline Other ${ }^{\mathrm{z}}$ & 0.7 & 0.0 & 0.2 & 0.0 & 0.5 & 14.6 & 0.0 & 0.9 \\
\hline
\end{tabular}

z Stemphylium vesicarium, Phomopsis mali, Diaporthe ambigua, Botryosphaeria dothidea, and some unidentified yeast genera. 
rot caused by Monilinia laxa and M. fructigena, black rot caused by Botryosphaeria obtusa, sour rot caused by Geotrichum candidum, and wet core rot caused by Fusarium avenaceum and $F$. proliferatum, varied widely by cultivar and year. In general, these latter pathogens occurred sporadically in decayed apple fruit at frequencies of 0 to $5.3 \%$ and, thus, are considered minor diseases.

Fruit quality, phytochemicals, and antioxidant activity. Granny Smith and Fuji apple fruit were significantly firmer (66.39 and $64.72 \mathrm{~N}$, respectively) compared with the other cultivars (Table 2). Fuji apple fruit had the higher SSC levels, followed by Red Delicious (14.2 and 13.2\%, respectively). Granny Smith was the most acidic cultivar ( $\mathrm{pH}$ value of 3.6$)$. The acidity content $(0.90 \%$ malate acid) of this cultivar was almost twofold higher compared with the other cultivars. Golden Delicious had the highest carotenoid levels (0.25 mg $\beta$-CE $100 \mathrm{~g}^{-1}$ f.w.) and Granny Smith had the lowest (Table 2). Total flavonoid content was almost 1.5 times higher on Red Delicious and Granny Smith apple fruit (40.65 and $40.26 \mathrm{mg} \mathrm{CE} 100 \mathrm{~g}^{-1}$ f.w., respectively) compared with the other cultivars. The highest amount of total phenolics was recorded on Red Delicious followed by Granny Smith (125.16 and $116.98 \mathrm{mg}$ GAE $100 \mathrm{~g}^{-1}$ f.w.). The antioxidant activity of the apple extracts, as estimated by the DPPH method, was higher for Red Delicious than

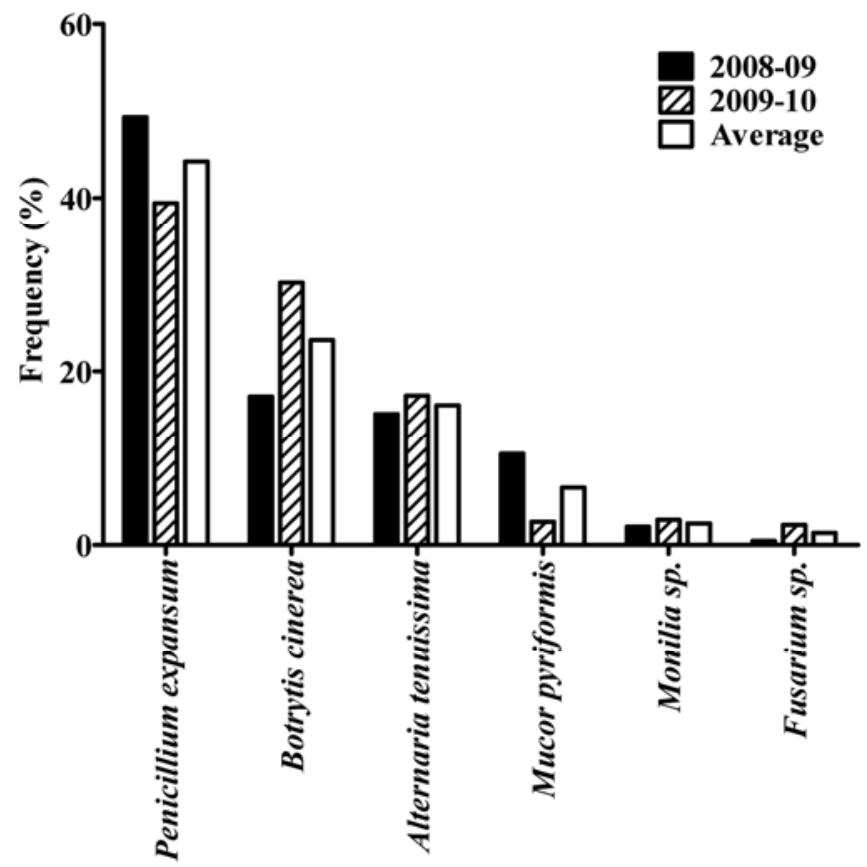

Fig. 1. Incidence (percentage of rotted fruit) of postharvest fungal pathogens of apple fruit collected from packinghouses in Greece during 2008-09 and 2009-10 storage periods. on Granny Smith, but both had significantly higher antioxidant activity than Golden Delicious and Fuji (Table 2).

Cultivar susceptibility to gray mold and blue mold. The average growth for lesions caused by $P$. expansum on fruit incubated at 2 and $22^{\circ} \mathrm{C}$ ranged from 0.4 to 0.9 and 3.9 to $5.1 \mathrm{~mm} /$ day, respectively. Similarly, for Botrytis cinerea, the average growth on fruit incubated at $22^{\circ} \mathrm{C}$ ranged from 2.6 to $4.9 \mathrm{~mm}$ /day whereas, at $2^{\circ} \mathrm{C}$, the average lesion growth ranged from 0.55 to $1.0 \mathrm{~mm} /$ day. Measurements of lesion diameter on the inoculated fruit showed that Golden Delicious was the most susceptible to blue mold at both temperatures, while Fuji was the most susceptible cultivar to gray mold when fruit were incubated at $22^{\circ} \mathrm{C}$ (Table 3). At $2^{\circ} \mathrm{C}$, Fuji and Golden Delicious fruit were equally $(P>0.05)$ susceptible (Table 3). Granny Smith and Red Delicious were the most resistant cultivars to blue mold at both incubation temperatures, with lesion diameters significantly lower $(P<0.05)$ than those in Fuji and Golden Delicious (Table 3). Red Delicious was significantly $(P<$ 0.05 ) more resistant to gray mold than Golden Delicious and Fuji, while susceptibility of Granny Smith fruit was intermediate at both incubation temperatures and similar $(P>0.05)$ to that of Red Delicious or Golden Delicious and Fuji fruit (Table 3).

Calculations of Pearson correlation coefficients among the qualitative characteristics of fruit used in the artificial inoculation assays and the lesion diameter caused by both pathogens on fruit incubated at $22^{\circ} \mathrm{C}$ showed that susceptibility to gray mold was negatively correlated with flavonoid $(r=0.91)$ and phenolic concentration $(r=0.89)$ as well with the fruit antioxidant activity $(r=0.91)$ (Table 4$)$. None of the remaining parameters measured was correlated $(P>0.05)$ with the susceptibility to gray mold. Susceptibility to $P$. expansum was negatively correlated $(P<0.05)$ to the fruit firmness and phenolic concentration, with $r$ values of 0.73 for both parameters (Table 4).

Patulin production. Initial studies for the patulin production, using TLC plates, showed that patulin was present in the four cultivars. Patulin production was significantly higher in Red Delicious and Golden Delicious fruit than Granny Smith and Fuji (Fig. 2). Calculation of Pearson correlation coefficients showed that patulin production in decayed apple tissues was negatively correlated with the firmness and the acidity of the fruit, with $r$ values of 0.93 and 0.83 , respectively (Table 4 ). In contrast, none of the remaining fruit qualitative parameters (carotenoids, flavonoids, phenolics, and antioxidant activity) tested were correlated $(P>0.05)$ to the patulin production.

\section{Discussion}

In this study, at least 14 different pathogens were associated with postharvest rot of apple in Greece, confirming previous reports that various fungal pathogens cause fruit rots on stored apple fruit (9). The pattern of pathogen distribution on the four cultivars was, to a great extent, similar during both years of the study. Among them, P. expansum, B. cinerea, A. tenuissima, and Mucor pyriformis were the most common and were found in the cultivars during both

Table 2. Quality parameters, chemical composition. and antioxidant activity of Red Delicious, Granny Smith, Golden Delicious. and Fuji apple fruit determined after harvest and before the artificial inoculation of the fruit ${ }^{\mathrm{t}}$

\begin{tabular}{|c|c|c|c|c|c|c|c|c|}
\hline Cultivar & $\begin{array}{l}\text { Firmness } \\
(\mathbf{N})\end{array}$ & $\begin{array}{l}\text { SSC } \\
(\%)^{\mathrm{u}}\end{array}$ & pH & $\begin{array}{l}\text { TA }(\text { malate } \\
\text { acid, \%) }\end{array}$ & $\begin{array}{l}\text { Carotenoids (mg } \beta- \\
\left.\text { CE } 100 \mathrm{~g}^{-1} \text { f.w. }\right)^{\mathrm{w}}\end{array}$ & $\begin{array}{c}\text { Flavonoids (mg CE } \\
100 \mathrm{~g}^{-1} \text { f.w.) }\end{array}$ & $\begin{array}{l}\text { Phenolics (mg GAE } \\
100 \mathrm{~g}^{-1} \text { f.w.) }\end{array}$ & $\begin{array}{c}\text { Antioxidant } \\
\text { activity }(\mathrm{mg} \mathrm{AEAC} \\
100 \mathrm{~g}^{-1} \text { f.w.) }\end{array}$ \\
\hline Red Delicious & $42.70 \mathrm{~b}$ & $13.32 \mathrm{~b}$ & $3.67 \mathrm{a}$ & $0.39 \mathrm{c}$ & $0.22 \mathrm{~b}$ & $40.65 \mathrm{a}$ & $125.16 \mathrm{a}$ & $186.95 \mathrm{a}$ \\
\hline Granny Smith & $66.40 \mathrm{a}$ & $11.15 \mathrm{~d}$ & $3.26 \mathrm{c}$ & $0.90 \mathrm{a}$ & $0.07 \mathrm{c}$ & $40.26 \mathrm{a}$ & $116.98 \mathrm{~b}$ & $161.22 \mathrm{~b}$ \\
\hline Golden Delicious & $35.01 \mathrm{c}$ & $11.85 \mathrm{c}$ & $3.42 \mathrm{~b}$ & $0.48 \mathrm{~b}$ & $0.25 \mathrm{a}$ & $27.58 \mathrm{~b}$ & $91.82 \mathrm{c}$ & $121.22 \mathrm{c}$ \\
\hline Fuji & $64.72 \mathrm{a}$ & $14.20 \mathrm{a}$ & $3.46 \mathrm{~b}$ & $0.50 \mathrm{~b}$ & $0.23 \mathrm{~b}$ & $24.72 \mathrm{c}$ & $93.90 \mathrm{c}$ & $125.53 \mathrm{c}$ \\
\hline
\end{tabular}

${ }^{t}$ Mean values of pooled data after testing homogeneity of variance of the two independent trials using Levene test $(P>0.05)$. Within columns, values

followed by the same letters did not differ significantly according to Fisher's protected east significant difference test $(P=0.05)$; f.w. $=$ fresh weight.

"Soluble solid content.

${ }^{\mathrm{T}} \mathrm{TA}=$ titratable acidity.

${ }^{\mathrm{w}} \beta-\mathrm{CE}=\beta$-carotene equivalents.

${ }^{x} \mathrm{CE}=$ catechin equivalents.

y $\mathrm{GAE}=$ gallic acid equivalents.

${ }^{\mathrm{z}} \mathrm{AEAC}=$ ascorbic acid equivalents antioxidant capacity. 
years of the study. These results are somewhat similar to two previously published reports, suggesting that blue and gray mold were the two most prevalent postharvest diseases of apple fruit in Washington State, United States, and British Columbia, Canada $(10,29)$. However, we found significant differences in the incidence of Alternaria spp. and $M$. pyriformis between our study and those previously mentioned. Alternaria spp. were identified only as a minor pathogen in both Washington State and British Columbia, whereas the incidence of $M$. pyriformis was low in Washington State but relatively high in British Columbia $(10,29)$. Such differences are probably related to the fact that apple fruit rot is a dynamic disease complex in which different fungal species predominate at different locations and that frequencies can vary greatly over time.

One of the most interesting differences observed among our results on pathogens incidence and those previously reported was the relatively high incidence of Alternaria spp. (10,29). Currently, Alternaria rot on apple fruit is considered to be relatively unimportant while leaf blotch caused by A. mali has received great attention (6). The taxonomy of the plant-pathogenic Alternaria spp. affecting several hosts is not clear. In our study, the small-spored Alternaria sp. isolated from the apple fruit was identified as $A$. tenuissima based on the ITS sequence of the isolates. However, because A tenuissima is considered to be mostly a species group rather than a single species, further research is required for more accurate identification of the isolates based on molecular differences and differences on the metabolite profile (1). Several previous studies reported Alternaria spp. as a fruit rot pathogen but they did not provide accurate identification at the species level $(10,29,32)$. Our identification matches two recent reports suggesting that isolates of Alternaria spp. obtained from apple flowers, leaves, or fruit belong in the A. tenuissima species group and have the potential to cause core rot in apple fruit (1). As mentioned, $A$. tenuissima was isolated from the four cultivars sampled during both sampling periods but, interestingly, in Fuji fruit, the incidence of A. tenuissima was significantly higher than that recorded for the

Table 3. Susceptibility (lesion diameter) of four apple cultivars to blue and gray mold diseases caused by Penicillium expansum and Botrytis cinerea, respectively

\begin{tabular}{llllll}
\hline & \multicolumn{4}{c}{ Lesion diameter $(\mathbf{m m})^{\mathbf{z}}$} \\
\cline { 2 - 3 } \cline { 5 - 6 } Cultivar & \multicolumn{2}{c}{ Blue mold } & & \multicolumn{2}{c}{ Gray mold } \\
\cline { 2 - 3 } \cline { 5 - 6 } & $\mathbf{2 2}^{\circ} \mathbf{C}$ & $\mathbf{2}^{\circ} \mathbf{C}$ & & $\mathbf{2 2}^{\circ} \mathbf{C}$ & $\mathbf{2}^{\circ} \mathbf{C}$ \\
\hline Red Delicious & $29.8 \mathrm{ab}$ & $16.5 \mathrm{ab}$ & & $18.5 \mathrm{a}$ & $16.5 \mathrm{a}$ \\
Granny Smith & $27.9 \mathrm{a}$ & $14.8 \mathrm{a}$ & & $24.3 \mathrm{ab}$ & $23.0 \mathrm{ab}$ \\
Golden Delicious & $36.0 \mathrm{c}$ & $26.2 \mathrm{c}$ & & $28.5 \mathrm{~b}$ & $29.8 \mathrm{~b}$ \\
Fuji & $30.9 \mathrm{~b}$ & $20.1 \mathrm{~b}$ & & $34.4 \mathrm{c}$ & $30.0 \mathrm{~b}$ \\
\hline
\end{tabular}

${ }^{y}$ Mean values of pooled data after testing homogeneity of variance of the two independent trials using Levene test $(P>0.05)$. Within columns, values followed by the same letter do not differ significantly according to Fisher's protected least significant difference test $(P=0.05)$.

${ }^{\mathrm{z}}$ Measurements of lesion diameter on the artificially inoculated fruit were carried out 7 and 30 days postinoculation on fruit incubated at 22 and $2^{\circ} \mathrm{C}$, respectively. remaining three cultivars. Alternaria spp. are considered to be mainly a core rot pathogen and, consequently, require fruit with an open sinus to enter the fruit. The high frequency of A. tenuissima observed in Fuji fruit may be related to the higher number of fruit with open sinus in Fuji compared with that in the remaining other cultivars tested (31).

The incidence of $F$. avenaceum and $F$. proliferatum found in this study was low. However, to the best of our knowledge, this is the first report of postharvest rot of apple fruit caused by these two Fusarium spp. in Greece. F. avenaceum and F. proliferatum are two of the most commonly encountered Fusarium spp. in small grains and maize (13); however, recently, a relatively high incidence of $F$. avenaceum on apple fruit was reported in Slovenia (28). Furthermore, Tournas and Uppal-Memon (32) reported that 3\% of apple fruit showed internal spoilage associated with Fusarium spp. Although the mycotoxigenic potential of A. tenuissima, $F$. avenaceum, and $F$. proliferatum isolated from apple fruit was not tested in this study, it is well known from previous studies that they may pose a mycotoxin risk $(1,30)$.

Information on the relative resistance of apple cultivars toward the most important postharvest diseases of apple fruit is limited $(10,31)$ and data were contradictory. This may be due, in part, to the absence of a common experimental design and similar cultivars. The results of our study showed that there was not a consistent pattern toward resistance or susceptibility to blue mold or gray mold in any of the four cultivars evaluated, suggesting that rot resistance among the four cultivars tested was nonspecific. Similarly, Spotts et al. (31) found no differences in gray mold and blue mold disease susceptibility among cultivars. However, the range of cultivars evaluated was different from ours and, consequently, a direct comparison of the results of these two studies is not possible.

Resistance of apple tissues to fungal decay is affected by several biochemical parameters. In this study, phenolic content of the fruit tissue was negatively correlated with the development of both diseases. In addition, gray mold development was negatively correlated with the flavonoid content and antioxidant activity of the fruit. The phenolic composition of apple fruit is highly variable and cultivar is one among the several factors that regulate phenolic contents (22). The negative correlation between disease severity and phenolic content observed in our study may be correlated with the production of phytoalexins, which are low molecular weight compounds of phenolic nature constituting an important part of the plant defense mechanisms. Such a hypothesis is consistent with the findings of a recent report which showed that exogenous application of several phenolic compounds resulted in lower $P$. expansum growth and patulin production (26). Similarly, preformed or induced flavonoids play a major role in postharvest resistance of fruit (33). Ambient $\mathrm{pH}$ is considered to be one of the most important factors regulating the secretion of cell-wall-degrading enzymes associated with the aggressiveness of fruit rot-associated fungi. Previous studies have shown that both $B$. cinerea and $P$. expansum are more aggressive in low-pH environments, which induce the expression of polygalacturonases $(23,24,34)$. However, the results of our study showed that fruit $\mathrm{pH}$ values were not correlated with

Table 4. Pearson correlation coefficients among apple fruit quality and compositional parameters, cultivar susceptibility (determined as lesion diameter) to blue and gray mold, and patulin production by Penicillium expansum ${ }^{2}$

\begin{tabular}{|c|c|c|c|}
\hline \multirow[b]{2}{*}{ Fruit quality and compositional parameters } & \multicolumn{2}{|c|}{ Lesion diameter at $22^{\circ} \mathrm{C}$} & \multirow[b]{2}{*}{ Patulin production } \\
\hline & Botrytis cinerea & Penicillium expansum & \\
\hline Firmness & 0.34 & $-0.73 *$ & $-0.93 *$ \\
\hline Soluble solid content & 0.30 & -0.02 & 0.22 \\
\hline Titratable acidity & -0.04 & -0.53 & $-0.83^{*}$ \\
\hline $\mathrm{pH}$ & -0.38 & 0.09 & $0.79 *$ \\
\hline Carotenoids & 0.27 & $0.73^{*}$ & 0.73 \\
\hline Flavonoids & $-0.91 *$ & -0.67 & 0.01 \\
\hline Phenolics & $-0.89 *$ & $-0.73^{*}$ & 0.07 \\
\hline Antioxidant activity & $-0.91 *$ & -0.67 & 0.19 \\
\hline
\end{tabular}

${ }^{\mathrm{z}}$ Asterisks $\left({ }^{*}\right)$ indicate $r$ value significant at $P=0.05$. 
the disease severity caused by either of these pathogens, suggesting that other physiological factors and their changes during the ripening process may also contribute to the interactions among the two pathogens and the apple tissue.

Measurements of patulin accumulation in the juice of the decayed tissue after artificial inoculation with $P$. expansum and incubation for 10 days at $20^{\circ} \mathrm{C}$ revealed marked differences among the four cultivars tested. Although patulin accumulated at high concentrations in the four cultivars, it was significantly higher in Red and Golden Delicious fruit than Granny Smith and Fuji. The finding that Golden Delicious fruit accumulated higher concentration of patulin than Fuji fruit at $20^{\circ} \mathrm{C}$ is in agreement with the findings of a previous study comparing patulin accumulation in these two cultivars $(14,25)$ but contradicts the findings of another study (19). Thus, it can be concluded that the cultivar itself is not the determinant factor for patulin accumulation. However, qualitative characteristics of the fruit, which are not affected only by the cultivar, may play a crucial role. In our assays, the Granny Smith fruit were more acidic and had lowest patulin concentration, while growth of $P$. expansum remained unaffected. Such a finding is in agreement with those of Marin et al. (14), who suggested that fruit acidity is an important factor affecting patulin production.

In conclusion, identification of Fusarium spp. and Alternaria spp. as causal agents of postharvest rot in apple fruit in Greece, along with the confirmed prevalence of the patulin-producer fungus $P$. expansum and the atoxigenic pathogen $B$. cinerea, is of significant importance because they may be responsible for high quantitative yield losses. Furthermore, the toxigenic species can contribute to qualitative deterioration of the stored apple fruit considering that high amounts of apple juices and other by-products are consumed by a vulnerable population such as infants and young children (32). The results of the study can be used for making decisions for implementation of control strategies aiming at the reduction of yield losses and increasing food safety by decreasing mycotoxin contamination of apple fruit by-products.

\section{Acknowledgments}

I. S. Minas was financially supported by the Hellenic Scholarship Foundation. We thank T. J. Michailides and C. Crisosto for critical reading of an earlier version of the manuscript and helpful suggestions.

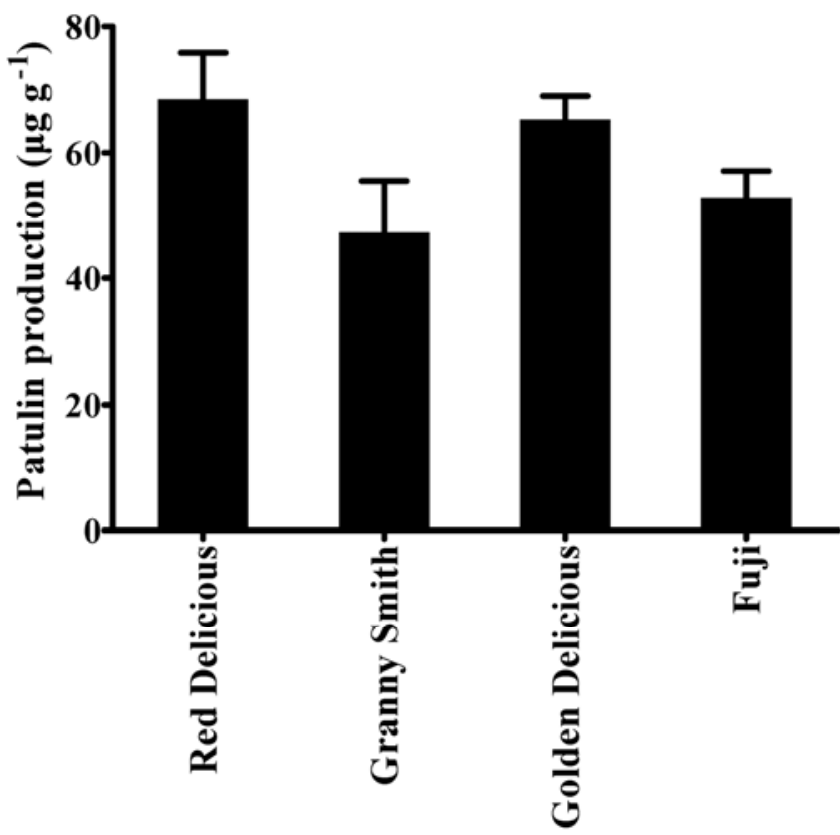

Fig. 2. Patulin production in artificially inoculated fruit of four apple cultivars by Penicillium expansum. Measurements were made after 10 days of incubation at $22^{\circ} \mathrm{C}$. Data were pooled after testing homogeneity of variance of the two independent trials using Levene test $(P>0.05)$. Bars on the columns indicate standard error of the mean.

\section{Literature Cited}

1. Andersen, B., Smedsgaard, J., Jorring, I., Skouboe, P., and Pedersen, L. H. 2006. Real-time PCR amplification of the AM-toxin gene and HPLC qualification of toxigenic metabolites from Alternaria species from apples. Int. J. Food Microbiol. 111:105-111.

2. Barnett, H. L., and Hunter, B. B. 1998. Illustrated Genera of Imperfect Fungi, 4th ed. American Phytopathological Society, St. Paul, MN.

3. Brand-Williams, W., Cuvelier, M. E., and Berset, C. 1995. Use of free radical method to evaluate antioxidant activity. Food Sci. Technol. 28:25-30.

4. Coates, L. M., and Johnson, J. I. 1997. Postharvest diseases of fruit and vegetables. Pages 533-548 in: Plant Pathogens and Plant Diseases. J. F. Brown, and H. J. Ogle, eds. Rockvale Publications, Armidale, Australia.

5. Cvek, J., Medic-Saric, M., Jasprica, I., Zubcic, S., Vitali, D., Mornar, A., Vedrina-Dragojevic, I., and Tomic, S. 2007. Optimisation of an extraction procedure and chemical characterisation of Croatian propolis tinctures. Phytochem. Anal. 18:451-459.

6. Filajdic, N., and Sutton, T. B. 1992. Influence of temperature and wetness duration on infection of apple leaves and virulence of different isolates of Alternaria mali. Phytopathology 82:1279-1283.

7. Frisvad, J. C., Thrane, U., Samson, R. A., and Pitt, J. A., 2006. Important mycotoxins and the fungi which produce them. Pages 3-31 in: Advances in Food Mycology. A. D. Hocking, R. A., Samson, J. I. Pitt, and U. Thrane, eds. Springer.

8. Jijakli, M. H., and Lepoivre, P. 2004. State of the art and challenges of postharvest disease management in apples. Pages 59-94 in: Fruit and Vegetable Diseases, Vol. 1. K. G. Mukerji, ed. Kluwer Academic Publishers, Dordrecht, The Netherlands.

9. Jones, A. L., and Aldwincle, H. S., eds. 1990. Compendium of Apple and Pear Diseases. American Phytopathological Society, St. Paul, MN.

10. Kim, Y. K., and Xiao, C. L. 2008. Distribution and incidence of Sphaeropsis rot in apple in Washington State. Plant Dis. 92:940-946.

11. Kuti, J. O. 2004. Antioxidant compounds from four Opuntia cactus pear fruit varieties. Food Chem. 85:527-533.

12. Larkin, M. A., Blackshields, G., Brown, N. P., Chenna, R., McGettigan, P A., McWilliam, H., Valentin, F., Wallace, I. M., Wilm, A., Lopez, R., Thompson, J. D., Gibson, T. J., and Higgins, D. G. 2007. Clustal W and Clustal X version 2.0. Bioinformatics 23:2947-2948.

13. Logrieco, A., Bottalico, A., Mule, M., Moretti, A., and Perrone, G. 2003. Epidemiology of toxigenic fungi and their associated mycotoxins for some Mediterranean crops. Eur. J. Plant Pathol. 109:645-667.

14. Marin, S., Morales, H., Hasan, H. A. H., Ramos, A. J., and Sanchis, V. 2006. Patulin distribution in Fuji and Golden apples contaminated with Penicillium expansum. Food Addit. Contam 23:1316-1322.

15. Markoglou, A. N., Vattis, K., Dimitriadis, K., Doukas, E. G., and Ziogas, B. N. 2008. Effect of phenylpyrrole resistance mutations on mycotoxin production by Aspergillus carbonarius and Penicillium expansum. In: 9th Int. Congress Plant Pathol. Torino, Italy.

16. Michailides, T. J., Morgan D. P., and Luo, Y. 2010. Epidemiological assessments and postharvest disease incidence. Pages 69-88 in: Postharvest Pathology, Plant Pathology in the 21st Century, Vol. 2. D. Prusky, and M. L. Gullino, eds. Springer Science + Business Media B.V., Dordrecht, the Netherlands.

17. Michailides, T. J., and Spotts, R. A. 1990. Postharvest diseases of pome and stone fruits caused by Mucor piriformis in the pacific Northwest and California. Plant Dis. 74:537-543.

18. Moake, M. M., Radilla-Zakour, O. I., and Worobo, R. W. 2005. Comprehensive review of patulin control methods in foods. Compr. Rev. Food Sci. Food Safety 1:18-21.

19. Morales, H., Barros, G., Marin, S., Chulze, S., Ramos, A. J., and Sanchis, V. 2008. Effects of apple and pear varieties and $\mathrm{pH}$ on patulin accumulation by Penicillium expansum. J. Sci. Food Agric. 88:2738-2743.

20. Morales, H., Marin, S., Obea L., Patino, B., Doménech, M., Ramos, A. J., and Sanchis, V., 2008. Ecophysiological characterization of Penicillium expansum population in Lleida (Spain). Int. J. Food Microbiol. 122:243-252.

21. Morales, H., Sanchis, V., Rovira, A., Ramos, A. J., and Marín, S., 2007. Patulin accumulation in apples during postharvest: effect of controlled atmosphere storage and fungicide treatments. Food Control 18:1443-1448.

22. Napolitano, A., Cascone, A., Graziani, G., Ferracane, R., Scalfi, L., di Vaio, C., Ritieni, A., and Fogliano, V. 2004. Influence of variety and storage on the polyphenol composition of apple flesh. J. Agric. Food Chem. 52:65266531

23. Prusky, D., Alkan, N., Miyara, I., Barad, S., Davidzon, M., Kobiler, I., Brown-Horowitz, S., Lichter, A., Sherman, A., and Fluhr, R. 2010. Mechanisms modulating postharvest pathogen colonization of decaying fruits Pages 43-55 in: Postharvest Pathology, Plant Pathology in the 21st Century, Vol. 2. D. Prusky, and M. L. Gullino, eds. Springer Science + Business Media B.V., Dordrecht, the Netherlands.

24. Prusky, D., McEvoy, J. L., Saftner, R., Conway, W. S., and Jones, R. 2004. Relationship between host acidification and virulence of Penicillium spp. on apple and citrus fruit. Phytopathology 94:44-51.

25. Salomao, B. C., Aragao, G. M., Churrey, J. J., Padilla-Zakour, O. I., and Worobo, R. W. 2009. Influence of storage temperature and apple variety on patulin production by Penicillium expansum. J. Food Prot. 72:1030-1036. 
26. Sanzani, S. M., De Girolamo A., Schena, L., Solfrizzo, M., Ippolito, A., and Visconti, A. 2009. Control of Penicillium expansum and patulin accumulation on apples by quercetin and umbelliferone. Eur. Food Res. Technol. 228:381-389.

27. Scalbert, A., Monties, B., and Janin, G. 1989. Tannins in wood: comparison of different estimation methods. J. Agric. Food Chem. 37:1324-1329.

28. Schroers, H-J., Sorensen J. L., Thrane U., Nielsen K. F., Jerjav, M., Munda, A., and Frank, J. 2008. High incidence of Fusarium avenaceum (Ascomycota, Nectriaceae, Gibberella) and moniliformin in apples showing wet core rot symptoms. J. Plant Pathol. 90:S2:326.

29. Sholberg, P. L., and Haag, P. D. 1996. Incidence of postharvest pathogens of stored apples in British Columbia. Can. J. Plant Pathol. 18:81-85.

30. Sorensen, J. L., Phipps, R. K., Nielsen, K. F., Schroers, H-J., Frank, J., and
Thrane, U. 2009. Analysis of Fusarium avenaceum metabolites produced during wet apple core rot. J. Agric. Food Chem. 57:1632-1639.

31. Spotts, R. A., Cervantes, L. A., and Mielke, E. A. 1999. Variability in postharvest decay among apple cultivars. Plant Dis. 83:1051-1054.

32. Tournas V. H., and Uppal Memon S. 2009. Internal contamination and spoilage of harvested apples by patulin-producing and other toxigenic fungi. Int. J. Food Microbiol. 133:206-209.

33. Treutter, D. 2006. Significance of flavonoids in plant resistance: a review. Environ. Chem. Lett. 4:147-157.

34. Wubben, J. P., ten Have, A., van Kan, J. A. L., and Visser, J. 2000. Regulation of endopolygacturonase gene expression in Botrytis cinerea by galacturonic acid, ambient $\mathrm{pH}$ and carbon catabolite repression. Curr. Genet. 37:152-157. 